\title{
MANAJEMEN PELAKSANAAN PROGRAM BIDANG PENANGANAN FAKIR MISKIN PADA DINAS SOSIAL KOTA KENDARI
}

\author{
'Adrian Tawai, ${ }^{2}$ Muhammad Yusuf, ${ }^{3}$ Suryana Mekuo \\ 1,2,3 Jurusan IImu Administrasi Publik FISIP, Universitas Halu Oleo \\ Email: adriantawai@uho.ac.id \\ Kota Kendari 93111, Indonesia
}

\begin{abstract}
This study aims to find out about the Management of the Implementation of the Program for Handling the Poor at the Kendari City Social Service. The method used in this study is a qualitative descriptive research method by means of observation, interviews and documentation. The results of this study indicate that the management of the implementation of the poor program carried out by the Kendari City Social Service is management carried out by taking into account the level of problems, objectives, strategies, activity programs, results to be achieved and schedule of activities. Likewise, the objectives and strategies are carried out in accordance with the existing activity programs at the Social Service in terms of handling the poor. the existing social masters so that they still need the next stage to be able to accommodate the poor. The schedule of activities is all carried out with an emphasis on the action plans carried out by the Social Service in every activity carried out as well as the existing poor program activities.
\end{abstract}

\section{Keywords: Handling the Poor; Management; Program Implementation}

\begin{abstract}
Abstrak
Penelitian ini bertujuan Untuk mengetahui tentang Manajemen Pelaksanaan Program Bidang Penanganan Fakir Miskin Pada Dinas Sosial Kota Kendari.Metode yang digunakan dalam penelitian ini adalah metode penelitian deskriptif kualiatif dengan cara observasi, wawancara dan dokumentasi. Hasil Penelitian ini menunjukan bahwa manajemen pelaksanaan program fakir miskin yang dilakukan oleh Dinas Sosial Kota Kendari merupakan manajemen yang dilakukan dengan memperhatikan pada tingkat persoalan, tujuan, strategi, program kegiatan, hasil yang akan dicapai dan jadwal kegiatan. Pada Tingkat persoalan manajemen pelaksanaan program dilakukan dengan memperhatikan tingkat persoalan yang ada sehingga masalah yang ada dapat diselesaikan, demikian pula halnya tujuan maupun juga strategi yang ada dilakukan sesuai dengan program kegiatan yang ada pada Dinas Sosial dalam hal penanganan fakir miskin. Untuk hasil yang dicapai masih memerlukan peningkatan dikarenakan masih terdapatnya masyarakat yang belum mendapatkan bantuan sosial yang ada sehingga masih memerlukan tahapan berikutnya untuk dapat mengakomodir masyarakat miskin tersebut. Jadwal kegiatan semuanya dilakukan dengan penekanan pada rencana aksi yang dilakukan oleh Dinas Sosial dalam setiap kegiatan yang dilakukan demikian juga dengan kegiatan program fakir miskin yang ada.
\end{abstract}

Kata Kunci: Manajemen: Pelaksanaan Program; Penanganan Fakir Miskin 


\section{Journal Publicuho}

ISSN2621-1351 (online), ISSN 2685-0729 (print)

Volume 4 Number 4 (November - January), (2021) pp. 1362-1370 Accredited SINTA SK.NOMOR 28/E/KPT/2019 Open Access at:http://ojs.uho.ac.id/index.php/PUBLICUHO/index $\quad$ DOl: http://dx.doi.org/10.35817/jpu.v4i4.23492

\section{PENDAHULUAN}

Kemiskinan merupakan masalah global yang dihadapi dan menjadi perhatian orang di dunia. Negara miskin masih dihadapkan antara masalah pertumbuhan dan distribusi pendapatan yang tidak merata sementara itu, banyak negara berkembang yang mengalami pertumbuhan ekonomi yang tinggi namun, kurang memberikan manfaat bagi penduduk miskinnya (Ayu Setyorini,2016). Kemiskinan merupakan permasalahan kronis yang kerap ditemui pada banyak negara, khususnya negara berkembang. Berbagai strategi telah diterapkan di beberapa negara dalam upaya pengentasan kemiskinan seperti program Bantuan Tunai Langsung di India, pemotongan pajak produk pertanian di China, serta dorongan untuk melakukan transformasi struktur ekonomi dari sektor pertanian menuju sektor manufaktur sebagaimana terjadi di Afrika. Namun demikian, penyelesaian masalah kemiskinan bukan hal yang sederhana, terbukti hingga saat ini masalah kemiskinan masih menghantui pemerintah di berbagai negara. Sektor apa yang harus tumbuh lebih cepat, mengapa dan bagaimana cara berinvestasi terbaik di sektor tersebut agar dapat memaksimalkan dampak pengentasan kemiskinan merupakan topik perdebatan para pembuat kebijakan di berbagai Negara. Kemiskinan dapat dikonotasikan sebagai suatu kondisi ketidakmampuan baik secara individu, keluarga, maupun kelompok, sehingga rentan terhadap timbulnya permasalahan lain terhadap berbagai aspek pembangunan. Kemiskinan di Negara Republik Indonesia sendiri terbilamg masih cukup tinggi dimana hal tersebut memerlukan penanganan yang khusus dan tepat sasaran serta program.

Salah satu permasalahan yang masih dihadapi oleh negara Indonesia yaitu masalah kemiskinan. Masalah kemiskinan merupakan masalah yang kompleks dan bersifat multidimensional sehingga menjadi prioritas pembangunan. Selama ini, pemerintah Indonesia telah banyak memiliki program-program untuk pengentasan kemiskinan yang ada Upaya pengentasan kemiskinan terdapat dua strategi yang harus di tempuh. Pertama, melindungi keluarga dan kelompok masyarakat miskin melalui pemenuhan kebutuhan mereka dari berbagai bidang. Kedua, melakukan pelatihan kepada mereka agar mempunyai kemampuan untuk melakukan usaha pencegahan terjadinya kemiskinan baru. Upaya pengentasan kemiskinan dilakukan untuk mewujudkan cita-cita bangsa yaitu, terciptanya masyarakat yang adil dan makmur (Debrina,2018). Sebagai negara berpenduduk terbesar keempat di dunia, permasalahan kemiskinan di Indonesia tidak hanya sebagai bagian dari pembangunan ekonomi, tetapi juga merupakan tantangan di bidang demografi. Hal ini tentu saja tidak lepas dari fakta masih terdapat 25,95 juta penduduk Indonesia yang tergolong dalam kriteria miskin (Evie Dian,2020). Angka ini setara dengan jumlah seluruh penduduk benua Australia bahkan lima kali lebih besar dari jumlah penduduk Singapura Di sisi lain, program pengentasan kemiskinan yang dicanangkan pemerintah 
seperti stabilisasi harga, pemberian bantuan tunai masyarakat dan penyaluran dana desa dipandang belum efektif mengurangi kemiskinan di Indonesia.

Kemiskinan merupakan salah satu persoalan mendasar, karena kemiskinan menyangkut pemenuhan kebutuhan yang paling mendasar dalam kehidupan dan kemiskinan merupakan masalah global karena kemiskinan merupakan masalah yang dihadapi banyak negara. salah satu sebab kemiskinan adalah karena kurangnya pendapatan dan aset (lack of income and assets) untuk memenuhi kebutuhan dasar seperti makanan, pakaian, perumahan, tingkat kesehatan dan pendidikan yang dapat diterima (acceptable). Di samping itu kemiskinan juga berkaitan dengan keterbatasan lapangan pekerjaan dan biasanya mereka yang dikategorikan miskin (the poor) tidak memiliki pekerjaan (pengangguran), serta tingkat pendidikan dan kesehatan mereka pada umumnya tidak memadai.

Kemiskinan merupakan masalah dalam pembangunan yang bersifat multidimensi karena dalam menanggulanginya masalah yang dihadapi bukan saja terbatas pada hal-hal yang menyangkut hubungan sebab akibat timbulnya kemiskinan tetapi melibatkan juga preferensi, nilai dan politik. Definisi tentang kemiskinan sangat beragam, mulai dari sekedar ketidakmampuan memenuhi kebutuhan konsumsi dasar dan memperbaiki keadaan, kurangnya kesempatan berusaha, hingga pengertian yang lebih luas yang memasukkan aspek sosial dan moral, Khomsan dkk (2015:1)

Menurut Angraeni dalam Khomsan dkk (2015:8) Kemiskinan merupakan masalah kompleks yang dipengaruhi oleh berbagai faktor yang saling berkaitan, antara lain: tingkat pendapatan, pendidikan, akses terhadap barang dan jasa, lokasi, geografis dan kondisi lingkungan. Kebutuhan pokok bisa diterjemahkan dalam suatu paket jasa dan barang yang dibutuhkan setiap orang untuk dapat hidup secara manusiawi terdiri dari keperluan air bersih, komposisi pangan bernilai gizi cukup, tingkat kesehatan, tingkat pendidikan dan yang terutama tempat tinggal.

Ada dua kategori kemiskinan, yaitu kemiskinan absolut dan kemiskinan relatif. Kemiskinan absolut mengacu pada satu set standar yang konsisten, tidak terpengaruh oleh waktu dan tempat atau negara. Contoh dari pengukuran absolut adalah persentase dari populasi yang makan di bawah jumlah yang cukup menopang kebutuhan tubuh manusia (kira kira 20002500 kalori per hari untuk laki laki dewasa). Adapun kemiskinan relatif ada lah ke-miskinan yang dilihat dari aspek ketim-pangan sosial, karena ada orang yang sudah dapat memenuhi kebutuhan dasar mini-mumnya tetapi masih jauh lebih rendah dibandingkan masyarakat sekitarnya (ling-kungannya). Semakin besar ketim-pangan antara tingkat penghidupan golongan atas dan golongan bawah maka akan semakin besar pula jumlah penduduk yang dapat dikategorikan miskin, sehingga kemiskinan relatif erat hubungannya dengan masalah distribusi pendapatan. 


\section{Journal Publicuho}

ISSN2621-1351 (online), ISSN 2685-0729 (print)

Volume 4 Number 4 (November - January), (2021) pp. 1362-1370 Accredited SINTA SK.NOMOR 28/E/KPT/2019 Open Access at:http://ojs.uho.ac.id/index.php/PUBLICUHO/index ～DOl: http://dx.doi.org/10.35817/jpu.v4i4.23492

Dari hasil observasi atau pengamatan awal peneliti melihat bahwa fakir miskin yang ada di Kota Kendari masih banyak sehingga masih memerlukan bantuan dan penanganan lebih lanjut.Data BPS Kendari jumlah kemiskinan masyarakat Kota Kendari selama tiga tahun terakhir pada tahun 2018 yaitu 17,76 ribu jiwa selanjutnya pada Tahun 2019 menjadi 17,30 ribu jiwa kemudian pada tahun berikutnya 2020 yaitu 17,46 ribu jiwa (BPS Kendari). Untuk itu maka peran pemerintah dalam melakukan penanganan fakir miskin sangat penting terutama pemerintah Kota Kendari yang memiliki kewenangan dalam hal tersebut yaitu pada Dinas Sosial Kota Kendari.Penanganan fakir miskin masih menjadi permasalahan yang serius dan merupakan salah satu masalah yang utama yang dihadapi oleh pemerintah Kota Kendari.

\section{METODOLOGI}

Metode yang dilakukan dalam penelitian ini yaitu menggunakan metode pendekatan kualitatif, yaitu suatu prosedur penelitian yang menghasilkan data deskriptif berupa tulisan dan perilaku yang dapat diamati dari subyek itu sendiri. Adapun jenis penelitian ini adalah penelitian kulitatif secara deskriptif yang bertujuan untuk mendeskripsikan apa-apa yang saat ini berlaku juga dimaksudkan sebagai proses pemecahan masalah yang diselidiki dengan melukiskan keadaan subyek obyek berdasarkan fakta-fakta yang ada. Teknik penentuan informan yang digunakan dengan pertimbangan tertentu atau penentuan informasi berdasarkan tujuan dan kebutuhanpeneliti, sehingga informan mampu memberikan keterangan dan informasi mengenai permasalahan dalam penelitian ini. Informan penelitian sebanyak 8 orang.Adapun sumber data dalam penelitianini adalah menggunakan data primer dan sekunder.Teknik pengumpulan data dilakukan dengan observasi, wawancara dan dokumentasi.

\section{HASIL DAN PEMBAHASAN}

\section{Manajemen Pelaksanaan Program Bidang Penanganan Fakir Miskin Pada Dinas Sosial Kota Kendari}

Pelaksanan program penanganan kemiskinan dalam kerangka pikir penelitian ini dapat dilihat dari analisi mengenai manajemen pelaksanaan program fakir miskin yang ada dan menurut Adisasmita (2011) bahwa manajemen program kerja ialah suatu kegiatan yang akan dilakukan dalam jangka waktu tertentu dan disusun secara terperinci. Di dalam program kerja terkandung unsur-unsur yaitu tingkat persoalan, Tujuan, Strategi, Program kegiatan, Hasil yang akan dicapai serta jadwal kegiatan

Dari keenam hal tersebut diatas maka dapat diketahui bahwasanya manajemen program yang ada disusun dalam enam aspek yang utama dimana keenam aspek ini adalah kegiatan yang dilakukan secara terperinci. Untuk mengetahui tentang keenam hal tersebut 
maka dilakukan penelitin dilapangan dengan wawancara yang dilakukan kepada para informan yang ada dan dianalisis satu persatu sesuai dengan hasil yang didapatkan.

\section{Tingkat Persoalan}

Tingkat persoalan yang dimaksudkan disini adalah manajemen yang dilakukan dengan melihat adanya tingkat persoalan yang ada kemudian dari hal tersebut juga dilakukan pemecahan terhadap persoalan yang ada dengan melihat kepada titik persoalan atau permasalahan yang mendasar dari program penanganan fakir miskin yang ada di Kota Kendari Provinsi Sulawesi Tenggara. Berdasarkan hasil pengamatan yang penulis lakukan di dalam tingkat persoalan ini maka yang dilakukan oleh dinas Sosial Kota Kendari mereka menjalin kerja yang ada dengan mengikuti alur yang telah ada dimana pegawai bekerja sesuai dengan program yang dijalankan dalam hal ini adalah pada bagian Program penangananan fakir miskin yang ada di Kota Kendari.

Penanganan kemiskinan yang ada di Kota Kendari memang berat dimana dengan kegiatan yang dilakukan maka mesti menjadikan masyarakat miskin menjadi lebih terbantu dengan apa yang telah dilakukan dan dikerjakan oleh Dinas Sosial Kota Kendari tersebut. Dari penelitian yang dilakukan maka diketahui bahwasanya tingkat persoalan yang ada pada penanggulangan kemiskinan yang ada di Kota Kendari dilakukan dengan melakukan pemetaan masalah yang ada dimana pemetaan masalah tersebut dapat diketahui mana pemetaan masalah yang tergolong kategori berat dan yang mana yang termasuk kategori yang ringan sehingga dengannya dapat dicarikan solusi masalahnya.Kemudian Tingkat persoalan yang paling ada biasanya dilakukan pemberian bantuan bantuan sosial yang memang sudah tersedia di Instansi Dinas Sosial Kota Kendari dan hal tersebut memang sudah menjadi program program dari Dinas Sosial Kota Kendari.Mengacu pada program kerja yang ada pada Dinas Sosia Kota Kendari maka program program yang dilakukan oleh Dinas Sosial Kota Kendari terdiri dari Pogram Pemuktahiran Data Base Terpadu (PBDT) Fakir Miskin,Program Bantuan Langsung Pemberdayaan Sosial (UEP-KUBE), Program Rehabilitasi Rumah Tidak Layak Huni (RS-RTLH), Sarana dan Prasarana Lingkungan (Sarling).

Dari hasil wawancara yang dilakukan kepada para informan yang juga merupakan masyarakat kurang mampu yang ada di Kota Kendari maka dari hak tersebut dapat diketahui bahwasanya tingkat persoalan yang ada memang sangat beragam dalam hal penanganan kemiskinan yang ada di Kota Kendari dimana tingkat persoalan yang ada diselesaikan dengan professional oleh Dinas Sosial Kota Kendari. Berdasarkan observasi yang penulis lakukan maka dalam hal tingkat persoalan yang ada dilakukan oleh pihak Pegawai pada Dinas Sosial Kota Kendari utamanya pada bagian Program Penanganan fakir miskin dimana dilakukan berdasarkan program program yang telah ada pada bagian Program Penanganan fakir miskin tersebut. 


\section{Journal Publicuho}

ISSN2621-1351 (online), ISSN 2685-0729 (print)

Volume 4 Number 4 (November - January), (2021) pp. 1362-1370 Accredited SINTA SK.NOMOR 28/E/KPT/2019 Open Access at:http://ojs.uho.ac.id/index.php/PUBLICUHO/index $\quad$ DOl: http://dx.doi.org/10.35817/jpu.v4i4.23492

\section{Tujuan}

Tujuan disini merupakan tujuan dari program penanganan fakir miskin dilakukan dimana dengan tujuan yang ada tersebut maka pihak Dinas Sosial Kota Kendari melakukan program penanganan kemiskinan dengan selalu mengacu kepada tujuan yang ada dan telah ditetapkan. Tujuan juga berkaitan dengan target yang ingin dicapai oleh Dinas Sosial Kota Kendari dalam merealisasikan apa yang menjadi tujuan penanganan fakir miskin yaitu membantu setipa keluarga miskin untuk keluar dari jeratan kemiskinan.

Dinas Sosial Kota Kendari melakukan langkah langkah dalam meraih tujuan yang ada terutama pada bagian Program Penanganan fakir miskin sebagai ujung tombak dari adanya kerja sosial penanganan fakir miskin tersebut.Labkah langkah yang dilakukan selalunya terkoordinasi dengan semua elemen yang ada di Dinas Sosial Kota Kendari sehingga keberhasilan tujuan yang dicapai adalah keberhasilan Dinas Sosial itu sendiri dan juga keseluruhan pemerintahan Kota Kendari. Tujuan yang diraih atau ingin diraih oleh Dinas Sosial Kota Kendari diperuntukan juga untuk keberlangsungan kehidupan mereka sehari hari dimana dengannya masyarakat miskin dapat mendapatkan bantuan pangan ataupun makanan serta uang tunai yang ada untuk membantu mereka sehari hari.

Dari hasil wawancara yang dilakukan maka dapat diketahui bahwasanya dari apa yang dikemukakan menggambarkan tentang manajemen yang baik yang dilakukan oleh pemerintah dalamhal ini adalah yang dilakukan oleh Dinas Sosial Kota Kendari Provinsi Sulawesi Tenggara. Berdasarkan observasi yang penulis lakukan maka diketahui bahwasanya dari segi tujuan yang ada menjadi pekerjaan yang selalu dilakukan oleh pihak bagian Program penanganan Fakir miskin dan bantuan bantuan yang ada diberikan kepada peneriman fakir miskin yang ada di Kota Kendari.

\section{Strategi}

Untuk meningkatkan efisiensi dan efektifitas program, serta agar mampu eksis dan unggul dalam persaingan yang semakin ketat dalam lingkungan yang berubah sangat cepat ini. Oleh karena itu, suatu instansi pemerintah harus secara terus-menerus melakukan perubahan ke arah perbaikan. Perubahan tersebut harus disusun dalam suatu tahapan yang konsisten dan berkelanjutan, sehingga dapat meningkatkan akuntabilitas dan kinerja yang berorientasi pada pencapaian hasil.

Strategi yang dilakukan oleh Dinas Sosial dalam melakukan manajemen pelaksanaan program penanganan fakir miskin dilihat dari adanya cara cara yang dilakukan yang menunjang berhasil atau tidaknya kegiatan yang dimaksudkan dalam hal ini adalah mengenai Program penanganan fakir miskin tersebut. Strategi yang dilakuka tentu saja mengenai langkah yang dilakukan yang berdasarkan visi misi dari Dinas Sosial Kota Kendari 
sehingga ketika bergerak dilapangan maka tidak akan pernah selalu terlepas dari yang namanya Visi Misi tersebut.

Dari hasil wawancara yang dilakukan tersebut maka dapat diketahui bahwasanya dari apa yang dikemukakan oleh informan yang ada menjelaskan tentang strategi yang baik yang telah dilakukan oleh pihak Dinas Sosial Kota Kendari dan semua kegiatan yang dilaksanakan tersebut mendapatkan hasil yang baik terhadap masyarakat yang kurang mampu. Berdasarkan observasi yang penulis lakukan maka dari segi strategi maka penulis melihat masih perlunya untuk terus meningkatkan strategi yang ada dimana strategi tersebut dapat lebih menjadikan suksesnya program yang ada terkait dengan penanganan fakir miskin.

\section{Program Kegiatan}

Program kegiatan yang dilakukan dalam penanganan kemiskinan yang dilakukan oleh Dinas Sosial Kota Kendari dilakukan dengan memperhatikan ketercapaian program yang ada dimana yang menangani langsung adalah dari bagian program penanganan fakir miskin.Untuk mengetahui tentang program kegiatan yang dimaksudkan disini dapat dilihat dari hasil wawancara yang dilakukankepada para informan. Program kegiatan yang dilaksanakan sebagaimana yang lainnya juga yang relah dibahas dalam penelitian ini adalah mengenai program kegiatan serta ketercapaian tujuan dan juga adanya keterkaitan dengan visi misi dari Dinas Sosial Kota Kendari itu sendiri.

Kegiatan yang telah dilakukan semuanya berdasarkan atau mengacu kepada tugas pokok dan fungsi yang ada serta juga melihat daripada besarnya manfaat atau kemaslahatan yang ada dari program kegiatan dan program kegiatan yang dilakukan dikerjakan degan penuh kesungguhan dan juga dengan kerjasama dari semua komponen yang ada di Dinas Sosial Kota Kendari. Dari hasil wawancara yang dilakukan maka dapat diketahui program program yang diberikan oleh pihak pemerintah yang ada di Kota Kendari sudah baik dan juga dalam hal bantuan yang diberikan sudah tepat sasaran dan membuat masyarakat menjadi senang dengan mendapatkan bantuan yang ada dari pemerintah. Observasi yang penulis lakukan bahwa yang menjadi program dari bidang penanganan fakir miskin dikerjakan dengan berdasarkan program yang telah tersedia dan menjadi rujukan untuk bagian program penanganan fakir miskin untuk bertindak.

\section{Hasil Yang Akan Dicapai}

Dalam melakukan program penanganan fakir miskin maka pemerintah Kota Kendar mesti memiliki target yang tepat dimana dalam pelaksanaannya dilakukan secara tepat sasaran kepada pihak fakir miskin yang ada di Kota Kendari.Untuk itu maka hasil yang dicapai yang dimaksudkan disini adalah tentang pelaksanaan program dimana dapat dinikmati oleh mereka kaum yang kurang mampu tersebut dan memiliki hasil yang memuaskan. Pencapaian atas apa yang telah dicapai juga bukan hanya dari kalangan instansi yang bersangkutan akan tetapi juga terlebih kepada masyarakat miskin yang ada sebagai focus 


\section{Journal Publicuho}

ISSN2621-1351 (online), ISSN 2685-0729 (print)

Volume 4 Number 4 (November - January), (2021) pp. 1362-1370 Accredited SINTA SK.NOMOR 28/E/KPT/2019 Open Access at:http://ojs.uho.ac.id/index.php/PUBLICUHO/index $\quad$ DOl: http://dx.doi.org/10.35817/jpu.v4i4.23492

atau obyek daripada kegiatan menyangkut penanganan kemiskinan yang ada pada Dinas Sosia Kota Kendari tersebut.

Hasil tersebut berkaitan dengan evaluasi yang dilakukan secara terus menerus disebabkan tanpa adanya hal yang demikian maka tidak akan diketahui kemajuan dari program program penanganan kemiskinan yang telah dilakukan dan juga terkait dnegan hasil maka untuk melihat keberhasilannnya bukan hanya dalam jangka waktu yang singkat akan tetapi dalam jangka panjang. Dari hasil wawancara yang dilakukan maka dapat diketahui hasil yang dicapai sudah baik dimana masyarakat yang kurang mampu mendapatkan bantuan yang ada dari pemerintah dalam hal ini dilaksanakan oleh pihak Dinas Sosial Kota Kendari. Berdasarkan observasi yang penulis lakukan maka dari segi hasil yang dicapai memerlukan evaluasi untuk ditingkatkan dan hasil yang dicapai sudah baik.

\section{Jadwal Kegiatan}

Jadwal kegiatan yang dilakukan dalam penanganan fakir miskin yang ada di Kota Kendari dilakukan dengan memperhatikan kegiatan yang dilaksanakan oleh bidang Penanganan program fakir miskin yang ada di Kota Kendari.Kegiatan dilakukan berdasarkan jadwal pembagian yang telah ditetapkan sehingga masing masing masyarakat penerima bantuan mendapatkan bantuan yang sesuai dengan apa yang mereka harapkan.

Dinas Sosial Kota Kendari menjadi wadah bagi pembagian bantuan yang ada selain itu juga bantuan yang diberikan berdasarkan ketepatan dalam pembagiannya dan juga adanya pemerataan kepada masyarakat miskin warga Kota Kendari.Hal tersebut tentu saja membutuhkan adanya kerjasama yang baik dengan pegawai yang lainnya yang ada di Dinas Sosial karena keberhasilan dari program yang ada merupakan keberhasilan semua yang bekerja di Dinas Sosial Kota Kendari. Masyarakat juga bisa mendapatkan bantuan melalui kantor Pos yang ada yang berupa Bantuan Langsung Tunai sehingga memudahkan masyarakat dan hal tersebut adalah merupakan kemudahan yang diberikan kepada masyarakat dalam menerima bantuan untuk keperluan hidup mereka.

\section{KESIMPULAN}

Dari hasil penelitian yang telah dilakukan maka dapat diberikan kesimpulan bahwasanya manajemen pelaksanaan program fakir miskin yang dilakukan oleh Dinas Sosial Kota Kendari merupakan manajemen yang dilakukan dengan memperhatikan pada tingkat persoalan, tujuan, strategi, program kegiatan,hasil yang akan dicapai dan jadwal kegiatan. Untuk hasil yang dicapai sudah baik dimana banyak masyarakat kurang mampu yang terbantu dengan program yang dilaksanakan oleh pihak Dinas Sosial Kota Kendari. Jadwal kegiatan semuanya dilakukan dengan penekanan pada rencana aksi yang dilakukan oleh Dinas Sosial dalam setiap kegiatan yang dilakukan demikian juga dengan kegiatan program fakir miskin yang ada di Dinas Sosial Kota Kendari Provinsi Sulawesi Tenggara. 


\section{REFERENSI}

Adisasmita, Tjokroadmudjoyo 2011. Pengelolaan Pendapatan dan Anggaran Daerah, Yogyakarta: Graha llmu.

Ayu Setyo Rini.2016. Faktor-Faktor Penentu Kemiskinan Di Indonesia: Analisis Rumah Tangga. Jurnal IImu Ekonomi Terapan. Desember 2016; 01 (2): 17-33 ISSN 2085-461

Azhar Arsyad. 2002. Pokok-Pokok Manajemen. Yogyakarta: Pustaka. Pelajar.

Cahyat, Gonner, C, and M Haug,2007. Mengkaji Kemiskinan dan Kesejahteraan Rumah Tangga: Sebuah Panduan dengan Contoh dari Kutai Barat, Indonesia, Bogor: CIFOR Indonesia

Debrina Vita Ferezagia.2018. Analisis Tingkat Kemiskinan di Indonesia. Jurnal Sosial Humaniora Terapan Volume 1 Nomor 1, juli-desember 2018.

Evie Dian Pratiwi.2020. Dampak Kemiskinan Terhadap Pola Mobilitas Tenaga Kerja Antarsektor Di Indonesia. Jurnal Kependudukan Indonesia | Vol. 15 No. 1 Juni 2020

Hasibuan, Malayu S.P, 2012. Manajemen Sumber Daya Manusia. Jakarta: PT Bumi Askara.

Hikmat, Harry. 2004. Strategi Pemberdayaan Masyarakat. Bandung: Humaniora utama press.

Khomsan, Ali, dkk. 2015. Indikator Kemiskinan dan Misklasifikasi Orang Miskin. Jakarta: Yayasan Pustaka Obor Indonesia.

Kuncoro, Mudrajad 2013 Mudah Memahami dan Menganalisis Indikator Ekonomi, Yogyakarta: UPP STIM YKPN

Munir dan Wahyu llaihi, 2006.Manajemen Dakwah Jakarta.PrenadaMedia Group

Notoatmodjo, Soekidjo.2009. Pengembangan Manajemen Sumber Daya Manusia, Jakarta: PT. Rineka Cipta

Nunung Nurwati.2008.Model pengukuran, permasalahan dan Alterbatif kebijakan.Jurnal Kependudukan Padjajaran.

Nurdin, Usman, 2002.Konteks Implementasi Berbasis Kurikulum. Jakarta Grasindo

Nurjanah, Ida. 2017. Analisis Faktor-Faktor Penyebab Kemiskinan Ditinjau dari Perspekif Ekonomi Islam. Jurnal Universitas Islam Negeri Raden Intan Lampung

Siti Hertanti.2019. Pelaksanaan Program Karang Taruna Dalam Upaya Meningkatkan Pembangunan Di Desa Cintaratu Kecamatan Parigi Kabupaten Pangandaran. Jurnal Moderat, Volume 5, Nomor 3, Agustus 2019

Siti Hertianti.2019. Pelaksanaan Program Karang Taruna Dalam Upaya Meningkatkan Pembangunan Di Desa Cintaratu Kecamatan Parigi Kabupaten Pangandaran.Jurnal Ilmu Pemerintahan. Vol 5, No 3 (2019)

Solihin, Ismail.2012.Pengantar Manajemen. Erlangga, Jakarta

Terry, George dan Leslie W. Rue. 2010. Dasar-Dasar Manajemen. Cetakan kesebelas. Jakarta: PT Bumi Aksara.

Wibowo, 2006.Manajemen Perubahan Edisi Ketiga, Jakarta Raja Grafindo..

Winda sari, Penerapan Fungsi Manajemen Dalam Pengelolaan Pepustakaan Jurnal Imu Informasi Kepustakaan dan Kearsipan", Volume 1 Nomor 1, edisi September 2012. 